\title{
The Impact of Task-Based Language Teaching on Iranian Female Intermediate EFL Learners' Writing Performance
}

\author{
Gholam Reza Parvizi (Corresponding author) \\ Department of English Language, Alborz University \\ Qazvin, I.R Iran \\ E-mail: Dr.reza.parvizii@gmail.com \\ Hooshang Khoshsima \\ Department of English Language, Chabahar Maritime University \\ Chabahar, I.R Iran \\ Mohammad Tajik \\ Department of Navigation, Immam Khomeini Maritime University \\ Noshahr, I.R Iran
}

Received: October 04, 2016 Accepted: November 01, 2016 Published: November 27, 2016

doi:10.5296/ijld.v6i4.10341 URL: http://dx.doi.org/10.5296/ ijld.v6i4.10341

\begin{abstract}
This article investigated the impact of task-based language teaching (TBLT) on writing performance of the Iranian intermediate EFL learners. There were two groups of forty students of the intermediate female learners studying English in Jahad-e-Daneshgahi language institute, ranging in age from thirteen to nineteen. They participated in their regular classes in the institute and were assigned to two groups including an experimental group of task-based language teaching and a control group for the purpose of homogeneity, all students in two groups took an achievement test before the treatment. As a pre-test; students were assigned to write a task at the beginning of the course. One of the classes was conducted through talking a TBLT approach on their writing, while the other class followed regular patterns of teaching, namely traditional approach for TBLT group. There were some tasks
\end{abstract}


chosen from learners' textbook. The task selection was in accordance with learning standards for ESL and TOFEL writing sections. At the end of the treatment, a post-test was administered to both experimental group and the control group. Scoring was done on the basis of scoring scale of "expository writing quality scale". The researcher used paired samples t-test to analyze the effect of TBLT teaching approach on the writing performance of the learners. The data analysis revealed that the subjects in TBLT group performed better on the writing performance post-test than the subjects in control group. The findings of the study also demonstrated that TBLT would enhance writing performance in the group of learners. Moreover, it was indicated that TBLT has been effective in teaching writing performance to Iranian EFL learners.

Keywords: Task-based language teaching, Task, Language teaching approach, Writing proficiency, EFL learners.

\section{Introduction}

Tasks have a central role in modern second language acquisition (SLA) research and especially in language pedagogy. It is in the natural setting where the word "task" entered language teaching through work with adults who needed to use the second language outside the classes (Allwrights, 1979; Breen, 1984; Nunan, 1989; 1993 as cited in Rosa , 2004).

The advent of "task" can be traced back from 1980s, responding to dissatisfaction with dominate principles of traditional methods which had resulted in disappointing outcomes and unsuccessful learners. At that time, tasks were considered as mechanisms for production phase of teaching a language (Norris).

Scholars have defined tasks in several different ways. Long (1985) has defined task as a piece of work undertaken freely or for the some rewards: painting a fence, filling out a form.... For Crooks (1986) task is a piece of work or activity with some specified objectives, as a part of educational course, or at work. While according to Bygate (2001), task is an activity which requires learners to use language with emphasis on meaning to attain an objective.

Considering the importance and implementation of task, Task-based language teaching approach has been proposed the notion of "task" in modern pedagogy followed communicative approaches of language teaching as the main pedagogical tool.

TBLT can be defined as a process-oriented approach to language teaching that focuses on communication (Little wood, 2004; Nunan, 2004; Richards, 2005 as cited in Lai \& Li, 2011). The basic point in Task-based language teaching is communicative tasks that serve as major units of curriculum while the primacy is on meaning (Lai \& Li, 2011). Recently, Task-based language teaching has gained great popularity among researchers, teachers and syllabus designers in a variety of educational settings due to its signs of crystallizing in to a robust domain of inquiry, with an international conference series (www.tblt.org), a book series (Task-based language teaching: issues, research and practice), and a healthy literature (Norris, 2009). 
Rod Ellis (2003) was the pioneer researcher who proposed and elaborated "Task-based" instructional approach, which encompasses tasks of various kinds to develop learners' communicative language ability. Harmer (2002 as cited in Rosa, 2004, p.208) summarized very clearly the stages of the TBL framework:

"In the pre-task, the teacher discusses the topic with the class and may highlight useful words and phrases, helping the students to understand the task instructions. The students may hear a recording of people doing the same task. During the task cycle, the students perform the task in pairs or small groups while the teacher monitors from a distance. The students then plan what they will tell the rest of the class, what they did and how it went, and they then report on the task either orally or in writing. In the language focus stage the students examine and discuss specific features of any listening or reading text which they have looked up for the task and the teacher may conduct some form of practice of specific language features which the task has provoked."

Wray (2011) believes the main feature of Task-based language teaching is that it emphasizes on the complexity of tasks and primacy of communication. Basically, according to Ellis (2003), TBLT involves taking task as the basic for the whole language curriculum, which is a unit of syllabus in language pedagogy by applying a procedural syllabus consisting graded set of tasks to be accomplished by students. He states that "tasks are seen not a means by which learners acquire new knowledge of restructuring their inter-language, but simply as a means by which learners can activate their existing knowledge of the L2 by developing fluency" (Ellis, 2003, p. 30).

Prabhu (1987) was the first researcher to consider task as the central notion of learning and teaching a language. Later, Foley (1991) described the psychological framework of TBLT. Moreover, in an attempt to operationalize Task-based theory, Brenda Dyer (1996) investigated L1 and L2 writing theories according to Hillock's environmental mode and Task-based language teaching. Hillock (1986) concluded that a Task-based, process / product combination was the most effective mode of teaching composition.

Consecutively, Swain and Lapkin (2000) examined the use of first language in Task-based language learning. They concluded that there was more use of L1 than was expected, so judicious use of L1 can support L2 learning. Focusing more on the details, Carless (2003) conducted a case study, implemented Task-based language teaching in Hong Kong to observe determining factors in the implementation of Task-based teaching in primary schools. Besides distinguishing the factors, he found out that examination would have some impact on what is going on in class, as well as the point that lack of teacher's proficiency will inhibit implementation of communicative approach.

More recently, Sánchez (2004) examined the role of Task-based approach in language teaching. Sánchez tried to bring positive results of using Task-based approach such as: more refined and complete foreign language syllabus, motivating students and focusing the attention of teachers and students on meaning and communicative language use. Meanwhile, Rosa (2004) investigated the effect of TBLT on young learners. He believed translation is a compulsory step, especially in reporting phase. One year later, in an attempt to reconsider 


\section{MInstitute ${ }^{\text {Mech }}$}

International Journal of Learning and Development

ISSN 2164-4063

2016, Vol. 6, No. 4

Task-based language learning, Slimani-Rolls (2005) claimed that one-way and decision-making tasks are preferred regarding language development.

During a case study for Korean Secondary School classroom practice, focusing on EFL teachers' perceptions of Task-based language teaching, Jeon and Jung - Won Hahn (2005) stated that majority of teachers have a higher level of understanding about TBLT, although there are some negative views on using TBLT in class practices. Moreover, Kuteeva (2006) focused on students' collaboration on Task-based communication in on-line forums. Additionally, Carless (2007) examined the suitability of TBLT for secondary schools in Hong Kong, resulting in more flexible version of TBLT; namely, Task-supported Language Teaching. As a comprehensive attempt, Adams (2009) collected and speculated all books and articles on the topic of TBLT, while Norris (2009) considered key principles of TBLT. Later, Zhao (2011) questioned the role of Task-based theories in combination with communicative and form-focused approaches. He approved superiority of Task-based language teaching over traditional methods. At the same time in Asia, Butler (2011) investigated implementation of communicative and Task-based language teaching in Asia-Pacific region. The researcher found TBLT being adopted and used in many countries, while facing some challenges like: conceptual constraints, classroom-level constraints and societal institutional level constraints.

Concerning local studies, TBLT implementation was examined by Rahimpoor (2006) proposing three kinds of TB syllabi, concluding that TBLT will lead to greater fluency and complexity among language learners.

Sadeghi and Fazelijou (2011) from Urmia University conducted a research focusing on the role of Task supported language teaching and Task-based language teaching in EFL learner's writing performance and grammar gains. They concluded students using revised PPP approach (TSL) learning did significantly better in grammar recognition section of the post-test, but students in Task-based language teaching did better on writings.

Considering tasks in TBLT, Maftoon and Haratmeh (2012) focused on the effectiveness of in-put - output-oriented tasks for vocabulary knowledge.

Moreover, Shabani and Ghasemi (2014), examined the effect of TBLT and CBLT (Context-based Language Teaching) on Iranian ESP learners' Reading Comprehension, preferring TBLT as more effective approach as the result.

Najjari (2014) conducted a research on the implementation of TBLT in Iran, concerning the barriers of TBLT. He resulted in a more flexible and more innovative version of TBLT to be implemented in Iran's context.

As it is clear, many studies have conducted on TBLT and its efficiency and importance so far, but to the researcher's best knowledge, few studies have focused on determining beneficial approach in teaching language, especially in the Iranian context and among intermediate EFL learners. Therefore, a research question has been formulated dealing with exploring the efficiency of Task-based Language Teaching on the development of writing proficiency. The study has addressed the following question: 


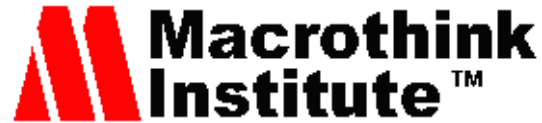

International Journal of Learning and Development

ISSN 2164-4063

2016, Vol. 6, No. 4

RQ: Does teaching writing through Task-based Language Teaching (TBLT) have any significant effect on Iranian intermediate EFL learners' writing proficiency?

\section{Research Methodology}

\subsection{Participants}

As the research question entails, the required participants need to be of the same intermediate level of second language proficiency. Since the purpose of this study is to examine potential and practical ideas for how Task-based Language Teaching can be applied to Iranian language learners, this study employed a quasi-experimental design including an experimental group and a control group of intermediate level of second language proficiency participants.

Forty intermediate female learners studying English in Jahad-e-Daneshghahi Language Institute were selected to take part in this research, ranging in age from thirteen to nineteen. They were researcher's students that participated in their regular classes in the institute who were assigned to three classes. Three students of each class were omitted due to age limitation or unmatched proficiency level after the homogeneity test. Random selection of participants in a class was impossible because they had already been assigned to their existing classes by the institute.

\subsection{Instruments}

To accomplish the purpose of the research, three instruments were determined as required for the study:

\subsubsection{Homogeneity Test}

In order to provide homogeneity, all students in both groups have taken an achievement test before conducting the treatment. The "General English Proficiency Test", Nelson (400B) was administered before the treatment. It consisted of four sections, i.e. vocabulary, structure, reading comprehension items. This was conducted to evaluate and ensure the proficiency level of students which was supposed to be the intermediate level. Among learners, based on their scores on Nelson proficiency test, those placed in intermediate level (within one standard deviation below and above the mean), were considered as main participants.

\subsubsection{Pre/Post-Test}

It is worth noticing that since the pre-test and post-test utilized in this study were researcher-made ones, they were piloted prior to use. Reliability indices for the pre- and post-test (0.70) revealed that the researcher-made tests were accepted for the purpose of the study. Besides, the test content was validated with regard to test instructions, the relevance of questions to content, its suitability to the research goals and objectives, and the suitability of the time allocated to the tests. The remarks of the validating team, their notes and suggestions were taken in to account, and the researcher made the necessary modifications before applying the test. 


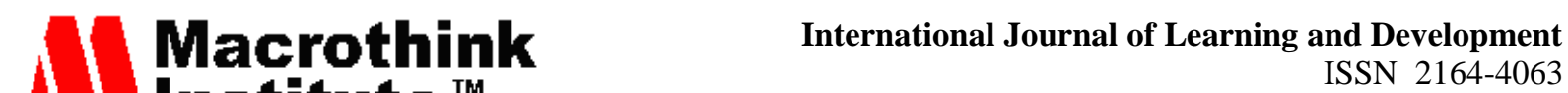 Institute"m}

\subsubsection{Scale for Assessing Writing}

The scale for Evaluating Expository Writing developed by Quellmalz (1982) was used as the framework in rating students' writing. This is a holistic analytic instrument that has six-point scales for assessing four dimensions of writing competence, focus/organization, support and mechanics. Inter-reliability test (using Cronbach alpha) indicates that the total reliability is 0.918 from the rators' perspectives and the reliability of each of them is obtained as 0.848 .

\subsection{Material}

The specifically regular text books of the institute are Top Notch Books series written by Saslow and Ascher (2005), which were chosen to be the base of the treatments of this study as they were the text book of the institute.

\subsection{Procedure}

This study has a quasi-experimental design including an experimental group and a control group. The participants needed to be of intermediate level of second language proficiency. In order to provide homogeneity, students in both groups took an achievement test before conducting the treatment.

Additionally, as a pre-test, students were assigned to write a task at the beginning. The treatments were about 20-30 minutes during each session. One of the classes received TBLT approach on their writing as the experimental group. For the experimental class, the teacher taught according to pre-task, task and post-task phases. The focus was on communication and meaning, but for the main focus was on tasks. Following the process of teaching tasks, students were asked to write about the topic in groups of two or three.

The task selection was in accordance with learning standards for ESL and TOFEL writing sections. Consequently, their writings were collected and scored by the teacher. For the end of the treatment, a post -test was administered to both experimental group and the control group. The writings were examined in terms of subject clearness, main idea clearness, beginning and end relevance, logical planning and the number of digressions. Scoring was done on the basis of scoring scale of "Expository Writing Quality Scale" 


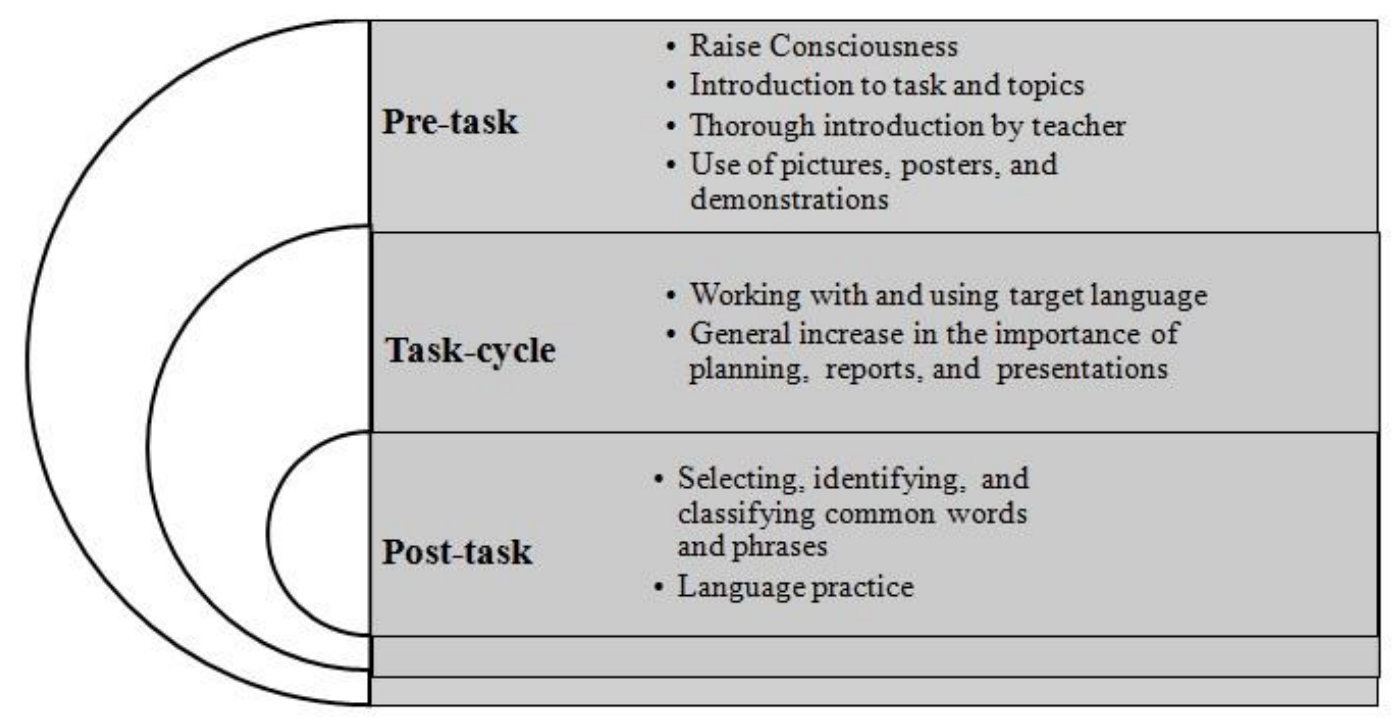

Figure1. The Structural Frame Work for TBLT

\section{Results}

Null hypothesis: Teaching writing through Task-based Language Teaching (TBLT) does not have significant effect on Iranian intermediate EFL learners' writing proficiency. In order to determine the kind of test running, the researcher uses Kolmogorov-Smirnov test to analyze the normal status of the related data.

Table 2:. One-Sample Kolmogorov-Smirnov Test for Tasked Based Language Teaching

\begin{tabular}{|l|l|l|}
\hline & & Task-based \\
\hline $\mathrm{N}$ & & 40 \\
\hline Normal Parameters a,b & Mean & 3.5438 \\
\hline Most Extreme Differences & Absolute & .188 \\
\hline Std. Deviation & 1.40955 \\
\hline Kolmogorov- Smirnov Z & & .188 \\
\hline Asymp. Sig.(2.tailed) & & -.152 \\
\hline
\end{tabular}


One can conclude from the obtained results, where the level of significance for Kolmogorov-Smirnov test is reported as 0.117 ( $\mathrm{P}$ value $>0.05$ ), that obtained results of this method confirm the normal status of the relevant data. Based on the results of Kolmogorov-Smirnov test, the researcher uses Paired- samples t-test to study this hypothesis. Prior to statistical analyses of the hypotheses, it is necessary to change the hypotheses to statistical hypotheses.

$\left\{\mathrm{H} 0: \mu_{1}=\mu_{2}\right.$

$\left\{\mathrm{H} 1: \mu_{1} \neq \mu_{2}\right.$

Table 3: Paired- samples t-test Regarding the Effect of Tasked-based Language Teaching

\begin{tabular}{|c|c|c|c|c|c|c|c|c|}
\hline & \multicolumn{2}{|c|}{ Paired Difference } & \multirow[b]{2}{*}{$\begin{array}{l}\text { Std. } \\
\text { Mean }\end{array}$} & & & \multirow[t]{2}{*}{$\mathrm{T}$} & \multirow[t]{2}{*}{ df } & \multirow[t]{2}{*}{$\begin{array}{l}\text { Sig. } \\
\text { (2tailed) }\end{array}$} \\
\hline & Mean & $\begin{array}{l}\text { Std. } \\
\text { Deviation }\end{array}$ & & \multicolumn{2}{|c|}{$\begin{array}{l}\text { Error } 95 \% \\
\text { Confidence } \\
\text { of the Difference }\end{array}$} & & & \\
\hline & & & & Lower & Upper & & & \\
\hline $\begin{array}{l}\text { Post - test/ } \\
\text { Pre - test }\end{array}$ & .83750 & .78755 & .17610 & .46892 & 1.20608 & 4.756 & 19 & .000 \\
\hline
\end{tabular}

Since significance level ( $\mathrm{p}$ value) is less than 0.05 (0.000), null hypothesis is rejected and alternative hypothesis is accepted i.e. teaching writing through task-based language teaching has significant effect on Iranian intermediate EFL learners' writing proficiency. In addition, $95 \%$ confidence interval $(1.20608,46892)$ is a positive value and this indicates that teaching writing through task-based language teaching has a positive effect on writing proficiency.

As seen in the above table, the level of significance pertinent to variables is less than 0.05 . It reveals that Task- based variable mean is significantly greater than that of control group. This implies that Task-based Language Teaching is more effective when compared to common traditional Language Teaching. Moreover, Task-based condition mean is significantly greater than that of control condition that proves the efficiency of TBLT on the learners' writing proficiency.

\section{Conclusion}

Based on the findings of the study, the researcher drew the conclusion that Task -based Language Teaching had significant effect on Iranian intermediate EFL learners' writing proficiency in isolation. Also, it is clear from the study findings that this approach had significant effect on Iranian intermediate EFL learners' writing proficiency when compared simultaneously with traditional common approach of language teaching (control group). 
Being in line with most current studies and researches on the issue of teaching methods; Task-based language teaching revealed to have great benefits in learning a language. Hismanoglu and Hismanoglu (2011) cited Ellis's (2009) list of the benefits such as:

- $\quad$ TBLT provides opportunity for 'natural' learning in class.

- It emphasizes on meaning, while stressing over learning form.

- It brings a fertile input of target language.

- It is motivating intrinsically.

- It is consistent with learner-focused educational psychology, but considers teacher input and guidance important.

- It encompasses improvement of communicative fluency but not ignoring accuracy.

- It can be deployed together with traditional approaches"(Hismanoglu \& Hismanoglu, 2011, p. 49).

It can be concluded that TBLT provides opportunities to set clear goals for the instructional courses; additionally, it ensures student-centered and authentic approaches to learning as well as providing multiple opportunities for input, production and feedback.

The findings of this study can be employed in classroom teaching and instruction. By considering the limitations of TBLT and adapting this method in Iranian context. The results of the study can be useful and helpful for instructors, researchers, syllabus designers and teachers in presenting efficient and effective writing tasks. Also text-book developers for junior and senior high schools may benefit from the findings of this study in designing new materials and possibly in changing the current grammar-based textbooks used in Iran. The experiences and concerns described in the paper may be shared by teachers to move from a teacher-centered approach which is the traditional approach of teaching in Iran, to one in which the learners play a more active, independent role to teach more and better namely Task-based Language Teaching.

\section{References}

Ahmadvand, M. \& Nejadansari, D. (2014). Attention to meaning and form vs. attention to meaning alone: The effect of focus on form on vocabulary retention of an EFL context. $\begin{array}{llll}\text { Procedia } & \text {-Social } & \& & \text { Behavioral }\end{array}$ Sciences.:98,2014,116-121.DOI:10.1016/j.sbspro.2014.03.396

Allen, P. (1984). Functional-analytic course design and the variable focus curriculum in Brumfit C. (ed.) ELT Documents 124: The Practice of Communicative Teaching. Oxford: Pergamon

Allwright, R. (1979). Language learning through communication practice in Broomfit C. \& K. Johnson (eds.). The communicative approach to language teaching.Oxford University Press 
Batstone, R. (1994). Grammar. Oxford: Oxford University Press.

Blake, R. \& Zyzik, E. El,(2003). Española y la lingüísticaaplicada. Georgetown University Press (forthcoming)

Breen, M. (1987).Learner contribution to task design.In C. Candlin and D. Murphy (eds.), Language learning

Brumfit, C. (1979). Communicative language teaching: An educational perspective in C. Brumfit and K. Johnson (eds) .

Butler, Y.G. (2011). The implementation of communicative and task-based language teaching in the Asia-pacific region. Annual Review of Applied Linguistics, 31, 36-57. Cambridge University Press

Bygate, M. (2001).Effects of task repetition on the structure and control of oral language. In M. Bygate, P. Skehan, \& M. Swain (Eds.), Researching pedagogic tasks: Second language learning, teaching and testing (pp. 23-48). Harlow/ New York: Longman

Cameron, L. (2001) Teaching languages to young learners. Cambridge University Press

Carless, D, R, (2003).Factors in implementation of task-based teaching in primary schools. System, 31,485500

Ciubancan, L, M, (2012).From task-supported teaching to task-based learning: the case of Japanese language teaching in Romania, academia.edu, Christian University

Crookes, G. (1989) Planning and interlanguage variation, Studies in Second Language Acquisition, 11, 367-383

Crookers, G. \& Choudron, C. (2001)."Guidelines for language classroom instruction"inM.CelceMurica(ed), Teaching English as a second or foreign language. Heinle\&Heinle Thomson Learning.

Dyer, B. (1996). L1 and L2 composition theories: Hillocks' environmental mode and task-based language Teaching.ELT journal, 50/4.

Ellis, R. (2003). Task-based language learning and teaching. Oxford: Oxford University Press

Ellis, R. (2010).Task-based language learning and teaching with technology. In M.Thomas $\& H$, Reinders (eds).New York/London :Continuum

Foster, P. \& Skehan, P. (1996). The influence of planning and task type on second language performance. Studies in second language acquition, 18, 299-323

Goto Butler, Y. (2011). The implementation of communicative and task-based language teaching in the Asia- Pacific Region.Annual Review of Applied Linguistics. 31, 36-57

Gowner, R. \& S.Walters. (1983). Teaching Practice Handbook. England: Oxford.

Hashemi, M., Aziznezhad, M. \& Darvishi, S(2012).Using task-based language teaching, learning practically in English classes. Procedia-Social\&Behavioral Sciences,31,526-529 
Jacobson, N. D. (2012). Applying cognitive linguistics and task-supported language teaching to instruction of English conditional phrases.GeorgetownUniversity. Washington,DC

Jeon, I.\& Hahn, J. (2005). Exploring EFL teachers' perceptions of task-based language teaching: A case study of Korean secondary school classroom. Asian EFL Journal .8(1) $123-143$

Kazerooni, A.(1995). Task-based language teaching. Asp[E linge],7-10

Klapper,J.(2003).Taking communication to task. A critical review of recent trends in language teaching.Language learning journal,27,33-42

Kotaka, M .(2013).Task-based language teaching and the Japanese English classroom. University of Hong Kong: Hong Kong

Lia, C.\& Li, G. (2011). Technology and task-based language teaching: a critical review. CALICO Journal, 28 (2), 498-521

Littlewood, W. (2004). The task-based approach: some questions and suggestions. ELT journal, 58, 319- 26.

Long, M. H. (1991). Focus on form: a design feature in language teaching methodology. In K. de Bot, R. B. Ginsberg, \& C. Karmsch (eds.), foreign language research in cross-cultural perspective (pp. 39-52). Amsterdam: John Benjamins

Maftoon, P. \& Haratmeh, M. S. (2012). The relative effectiveness of input and output-oriented tasks with different involvement loads on the receptive and productive vocabulary knowledge of Iranian EFL learners. The Journal of Teaching Language Skills.4 (2),67. 29-52

Müller, A., Schocker, M.\& Ditfurth, V.(2013). Teaching English: Task-supported language learning . Verlag Ferdinand Schoningh G mbH\& co. KG.Paderborn

Najjari, R.(2014). Implementation of task-based language teaching in Iran: Theoretical and practical considerations. Science Direct ,1307-1315.

Norris, J. M. (2009). Task based teaching and testing. The handbook of Language Teaching.Blackwell Publishing Ltd

Nunan, D. (1989). Designing tasks for the communicative classroom. Cambridge University Press.

Nunan, D. (1993). Task-based syllabus design: selecting, grading, and sequencing tasks in Gass

S \& G. Crookers (eds.), Tasks in a pedagogical context, Multilingual Matters

Quellmalz, E. (1982). Scale for evaluating expository writing. Journal of educational measurement, 6(4), 28- 40

Rahimpour, M.(2008). Implementation of task-based approaches to language 
teaching,Pazhuhesh-e Zabanhaye Khareji,41,45-61

Revesz, A., \& Han, Z. (2006).Task content familiarity, task type and efficacy of recasts. Language Awareness, 15(3), 160-179. Retrieved from ERIC database

Richards, J. C. (2005). Communicative language teaching today (RELC portfolio series 13). Singapore: SEAMEO regional language center

Robinson, P. (2001). Task complexity, task difficulty, and task production: Exploring interactions in a componential framework. Applied linguistics, 22, 27-57

Rosa, M. M. (2004). TBLT and young learners. Glosas Didacticas,11, 207-214

Sadeghi,K.\&Fazelijou,E(2011). The role of task-supported language teaching in EFL learner's writing performance and grammar gains. The southeast Asian Journal of English language studies, 18(1), 117-127

Samuda,V.,\& Bygate, M. (2008).Tasks in second language learning,Basingstoke:Palgrave Macmillan

Sanchez, A.(2004).The task-based approach in language teaching.Intrnational Journal of English Studies.4(1),39-71

Saslow,J. \& Ascher, A.(2005). Top Notch. Pearson Education, Inc.

Shabani,M. B.,\& Gasemi, A. (2014).The effect of task-based language teaching (TBLT) and content based language teaching(CBLT) on the Iranian intermediate ESP learners' reading $\begin{array}{lllll}\text { comprehension } & \text { Procedia } & \text { \& } & \text { Social B } & \text { Behavioral }\end{array}$ Sciences.:98,2014,1713-1721.DOI:10.1016/j.sbspro.2014.03.598

Skehan, P,(1996 b) .Second language acquisition research and task-based instruction in J. Willis and Willis and D. Willis

Silva, C.(2006 ).Task-supported language teaching with real beginners. Center for advancement of higher education, Tokyo University.203-208

Silmani-Rolls, A. (2005). Rethinking task-based language learning: what we can learn from learners.Language Teaching Research 9,2. pp. 195-218

Song M.-J., \& Suh, B.-R. (2008).The effect of output task types on noticing and learning of the English past counterfactual conditional.System, 36(2), 295-312

Swain, M, \& Lapkin, S. (2001). 'Focus on form through collaborative dialogue: Exploring task effects' in Bygate, M., Skehan, P., and Swain, M (eds). Researching Pedagogic tasks: Second Language Learning, Teaching, and Testing. New York: Longman. pp 99-118

Thomas, M., \&Reinders, H. (Eds.). (2010). Task-based language learning and teaching with technology. London: Continuum.

Van den Branden, K., bygate, M., \& Norris, J. M. (2009). Task-based language teaching: A reader. Amsterdam/Philadelphia: John Benjamins Publishing Company. 


\section{Macrothink \\ International Journal of Learning and Development \\ ISSN 2164-4063 2016, Vol. 6, No. 4}

Willis, J. (1996). A Framework for Task-based Learning.Harlow, UK: Longman

Willis, D., \& Willis, J. (2011).Doing task-based teaching. Oxford: OUP

Wray, A. (2011). Interim evaluation of Welsh for adults teaching materials in the light of current research. (Draft Consultative Report), Cardiff University

Zheng, X. ,\& Borg, S.(2014).Task-based learning and teaching in China: secondary school teachers beliefs and practice: Language Teaching Research,18(2),205-221

\section{Copyright Disclaimer}

Copyright for this article is retained by the author(s), with first publication rights granted to the journal.

This is an open-access article distributed under the terms and conditions of the Creative Commons Attribution license (http://creativecommons.org/licenses/by/3.0/). 